\title{
CONSTRUCTION SPIN COATING AS PRINTING EDIBEL FILM GANYONG
}

\author{
Endah Kurnia Yuningsih', Tuti Kurniati ${ }^{2}$, Neneng Windayani ${ }^{3}$, Rizki Zakwandi' ${ }^{1}$, Tiana \\ Azmi ${ }^{1}$
}

\author{
${ }^{1}$ Program Studi Pendidikan Fisika, Fakultas Tarbiyah dan Keguruan, UIN Sunan Gunung Djari \\ Bandung, Indonesia \\ ${ }^{2}$ Program Studi Pendidikan Biologi, Fakultas Tarbiyah dan Keguruan, UIN Sunan Gunung Djari \\ Bandung, Indonesia \\ 3Program Studi Pendidikan Kimia, Fakultas Tarbiyah dan Keguruan, UIN Sunan Gunung Djari \\ Bandung, Indonesia \\ E-mail: endahkurnia@uinsgd.ac.id
}

\begin{abstract}
ABSTRAK
Keberadaan makanan yang halal dan baik merupakan kebutuhan pokok bagi umat Islam. Menjaga kualitas makanan dari keutuhan zat gizi serta menjauhkannya dari sumber penyakit adalah salah satu upaya menciptakan kualitas makanan yang baik. Hal ini akan lebih bernilai apabila bisa dilakukan dengan bahan alam yang ada di sekitar masyarakat itu sendiri. Menumbuhkan kepedulian lingkungan dan kepekaan sosial pada generasi muda muslim adalah hal yang tidak bisa lepas dari pendidikan di bangku kuliah. Penelitian ini bertujuan untuk mengembangkan perangkat pembuatan bio-plastik yang berbahan dasarkan ganyong (Canna edulis) dengan pemanfaatan barang-barang bekas dan murah. Metode yang digunakan pada penelitian adalah Research and Development (R\&D). Mengembangkan perangkat Spin Coating agar sesuai dengan kebutuhan pencetakan edibel. Efektifitas alat yang dibuat terukur dari pengukuran faktor fisik bio-plastik yang dihasilkan berupa kekuatan, ketebalan dan daya tahan. Hasil penelitian menunjukkan hasil yang cukup optimal terutama pada faktor ketebalan. Ketebalan bio-plastik yang dihasilkan menggunakan spin coating modifikasi adalah $<0,5$ mm dengan pemutaran pada kecepatan tertentu, yaitu pada tegangan 12 volt dan suhu $60 \mathrm{o}-80 \mathrm{oC}$. Hasil bio plastik yng diperoleh dapat digunakan sebagai pembungkus makanan yang pada penelitian ini diterapkan sebagai pembungkus dodol. Sehingga kualitas gizi dodol dapat lebih tahan lama.
\end{abstract}

Kata kunci: Spin Coating, Edible Film

\begin{abstract}
The existence of halal and good food is a basic requirement for Muslims. Maintaining the quality of food from the integrity of nutrients and keep it away from the source of disease is one effort to create good quality food. This will be more valuable if it can be done with natural materials that exist around the community itself. Growing environmental awareness and social sensitivity on the young generation of Muslims is something that can not be separated from education in college. This research is aimed to develop bio-plastic making device based on ganyong (Canna edulis) with the utilization of used and cheap goods. The method used in the research is Research and Development $(R \& D)$. Develop Spin Coating devices to suit the needs of edible printing. The effectiveness of measurable measurements of physical bio-plastic factor measurements resulted in strength, thickness and durability. The results of this study show that the results are quite optimal, especially on the thickness factor. The thickness of bio-plastics produced using modified spin coating is $<0.5 \mathrm{~mm}$ with rotation at a certain speed, ie at 12 volts and $60 \mathrm{o}-80 \mathrm{oC}$. The result of bio-plastic obtained can be used as food wrapper which in this research is applied as dodol wrapping. So the quality of nutrition dodol can be more durable.
\end{abstract}

Keywords: Spin Coating, Edible Film

DOI: http://dx.doi.org/10.15575/jtlp.v2i1.6585

Received: 12 November 2016 ; Accepted: 30 Januari 2017; Published: 1 Maret 2017 


\section{PENDAHULUAN}

Permasalahan lingkungan yang dihadapi dewasa ini adalah permasalahan sampah plastik karena struktur penyususn plastik tidak dapat diuraikan secara alami oleh dekonposer. Sebagai alternatif pengatasan masalah tersebut dilakukan upaya pembuatan bio-plastik yang berasal dari bahan yang alami sehingga dapat diuraikan oleh bakteri secara alami. Penelitian kali ini bertujuan untuk mengembangkan alat spin coater yang mampu memproduksi bioplastik dengan memanfaatkan peralatan yang ada di lingkungan. Spin couting merupakan sebuah alat cetak edibel (bio-plastik) dengan menggunakan prinsip rotasi bahan pada plat yang diputar pada kecepatan tertentu dalam keadaan dipanaskan. Dalam penelitian ini spin couting diaplikasikan pada pencetakan edibel film nata de cana sebagai pembungkus dodol kacang merah dengan harapan ketebalan dibawah 0,5 mm sesuai standar SNI . Menurut Parija (2009). Spin coating saat ini merupakan teknik utama yang digunakan untuk menghasilkan film tipis tipis bahan organik fotosensitif dengan ketebalan orde mikrometer dan nanometer. (sahu, Parija, \& Panigrahi, 2009).

Spin coating yang beredar dan tersedia di laboratorium pada umumnya memiliki ukuran yang sangat besar $(\mathrm{d} \pm 30 \mathrm{~cm})$ dan memiliki kecepatan rotasi yang besar berkisar lebih dari 500rpm. Ukuran yang besar dinilai kurang efetif baik dari segi tempat dan juga dari sudut pandang penggunaan bahan dasar pembuatan bio-plastik, karena semakin besar ukuran wadah/cetakan maka adonan yang dibutuhkan juga semakin banyak. Dari sudut pandang kecepatan rotasi, merujuk pada bahan dasar pembuatan bio-plastik berupa adonan cair maka dengan kecepatan yang sangat tinggi adonan akan terlempar keluar. Pengembangan alat yang dilakukan untuk menutupi kekurangan hal tersebut dengan membuat spin coating berukuran minimalis (seukuran dengan dodol kacang merah, $d \pm 15 \mathrm{~cm}$ ). Selain itu pada pengatur kecepatan digunakan dinamo dengan rentang nilai kerja dari 3-24 volt.

Penelitian tentang proses pembuatan edible film selain spin coating sebelumnya telah banyak dilakukan. Secara umum penelitian terkait berfokus pada methode pembuatan diantaranya solvent-casting, washing cycle, wrapping dan dipping. pelarut atau teknik pencucian garam dengan hasil sebagai metode pelarut-casting melibatkan pertimbangan beberapa faktor penting, seperti jenis pelarut, tingkat penguapan pelarut, konsentrasi dan viskositas larutan polimer, jenis dan ukuran porogen, dan parameter casting (Taherkhani \& Moztarzadeh, 2016). Cara selanjutnya yaitu dengan roses washing cycle dengan hasil berupa "Hasilnya menunjukkan bahwa diameter rata-rata MWCNT dipertahankan pada ukuran yang hampir sama bahkan setelah tiga siklus pencucian. Pengamatan ini mengkonfirmasi ikatan kuat antara MWCNT dan $\beta$-CD" (Jawad, et al., 2017). Cara berikutnya yang dapat dilakukan untuk memperoleh edible film adalah dengan methoda wrapping sebagaimana yang dilakukan oleh Epifani dkk (2015) yang memberikan kesimpulan berupa "menghasilkan modifikasi struktural dan listrik dari anatase host. Sifat penginderaan etanol dari berbagai bahan diuji dan dibandingkan dengan TiO2 murni dan WO3 yang dipersiapkan secara analog. Mereka menunjukkan bahwa bahkan modifikasi permukaan sederhana dari host TiO2 menghasilkan tiga urutan peningkatan respons magnitude sehubungan dengan Ti02 murni (Eifani, et al., 2015)“Metode yang ke empat yaitu dengan mencelupkan/dipping sebagaimana yang dilakukan oleh Mulyadi (2014) dengan kesimpulan berupa metode dipping "Dalam penelitian ini, proses pelapisan yaitu pencelupan dan pengeringan kurang tepat sehingga lapisan yang terbentuk kurang merata. Untuk itu, perlu dicari metode pelapisan yang lebih tepat sehingga lapisan yang terbentuk lebih baik dan merata (Mulyadi, Kumalaningsih, \& Giovanny, 2014) 


\section{METODE PENELITIAN}

Spin coating ini dibuat dengan menggabungkan dua komponen utama yaitu pemanas komponen pemanas (coating) dan komponen pemutar (Spiner) .Desain spin coating hasil modifikasi adalah sebagai berikut:
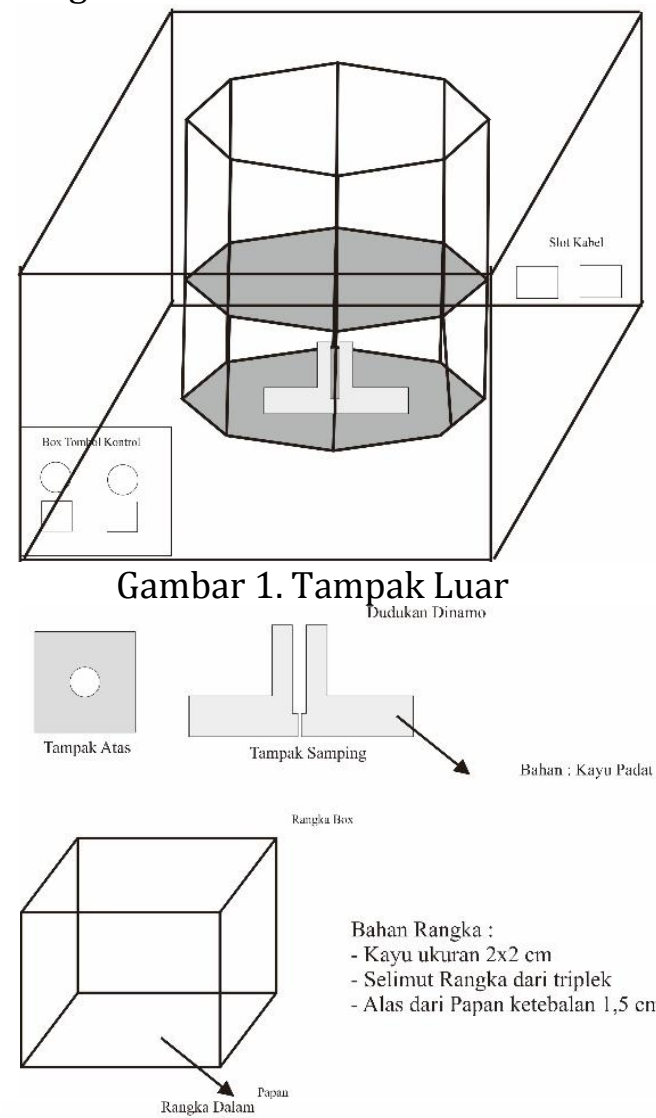

Bahan Rangka :

- Kayu ukuran $2 \times 2 \mathrm{~cm}$

Selimut Rangka dari triplek

Alas dari Papan ketebalan 1,5 cm

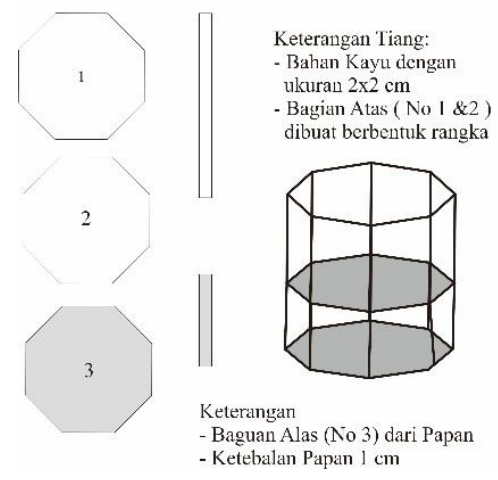

Gambar 2. Struktur Alat

1. Subjek

Penelitian ini dilakukan di laboratorium pendidikan biologi, pendidikan kimia dan pendidikan fisika UIN Sunan Gunung Djati

Bandung. Sasaran akhir dari penelitian ini adalah masyarakat ataupun industri yang memproduksi makanan kering untuk dibungkus dengan edible film dari bahan nabati.

2. Cara memperoleh data

Data pada penelitian adalah adalah kecepatan rotasi ideal, suhu ideal dan sebagai faktor pembanding adalah ketebalan dan kekuatan bioplastik yang dihasilkan. Pengambilan data dilakukan dengan memvariasikan kecepatan rotasi untuk memperoleh nilai kecepatan optimal untuk menghasilkan edible dengan ketebalan yang terbaik. Variasi kecepatan yang dilakukan adalah pada kecepatan $3 \mathrm{~V}, 6 \mathrm{~V}, 9 \mathrm{~V}$ dan 12V. Selanjutnya variasi suhu dilakukan untuk mengetahui suhu terbaik untuk menghasilkan edible dengan kekuatan yang bagus. Disamping dua variabel utama, faktor lainnya yang menjadi perhatian dalam penelitian ini adalah tingkat kekentalan atau massa jenis adonan karena hal ini akan berdampak pada penyebaran adonan oleh spiner.

3. Analisis

Data yang diperoleh kemudian dianalisis dengan memperhatikan besaran-besaran fisis pada produk yaitu ketebalan dan kekuatan dari edible. Penelitian yang dilakukan menargetkan ketebalan edibel berkisar pada nilai 0-0,5 $\mathrm{mm}$. Sehingga range pencapaian alat mengacu pada nilai tersebut. variabel kedua yaitu kekuatan dari edible yang dihasilkan. Kekuatan edible pada penelitian kali ini tidak memiliki nilai acuan tersendiri hanya pada faktor tingkat ketahanan yang mengacu pada kemudahan edible tersebut robek.

\section{HASIL DAN PEMBAHASAN}

Tabel 1. Data Pengamatan Karakteristik edible film

\begin{tabular}{|c|c|c|c|c|c|c|}
\hline No & Densitas & $\mathbf{V}$ & $\begin{array}{c}T \\
\left({ }^{\circ} \mathrm{C}\right)\end{array}$ & $\begin{array}{l}\text { Tebal } \\
(\mathrm{mm})\end{array}$ & Karakter & Sifat \\
\hline 1 & $\begin{array}{l}\text { Terlalu } \\
\text { Encer }\end{array}$ & 12 & 80 & $\begin{array}{l}<< \\
0,5 \\
\mathrm{~mm}\end{array}$ & Padu & $\begin{array}{l}\text { Sangat } \\
\text { Rapuh }\end{array}$ \\
\hline 2 & $\begin{array}{l}\text { Sedikit } \\
\text { Encer }\end{array}$ & $\begin{array}{c}12 \\
\text { volt }\end{array}$ & 80 & $\begin{array}{c}<< \\
0,5 \\
\mathrm{~mm} \\
\end{array}$ & $\begin{array}{l}\text { Tidak } \\
\text { Padu }\end{array}$ & $\begin{array}{l}\text { Sangat } \\
\text { Rapuh }\end{array}$ \\
\hline
\end{tabular}




\begin{tabular}{ccccccc}
\hline No & Densitas & $\mathbf{V}$ & $\begin{array}{c}\boldsymbol{T} \\
(\mathbf{o})\end{array}$ & $\begin{array}{c}\text { Tebal } \\
(\mathbf{m m})\end{array}$ & Karakter & Sifat \\
\hline \multirow{2}{*}{3} & Kurang & 12 & 80 & $<0,5$ & Tidak & Sangat \\
& Encer & volt & & $\begin{array}{c}\mathrm{mm} \\
<0,5\end{array}$ & $\begin{array}{c}\text { Padu } \\
\text { Tidak }\end{array}$ & Rapuh \\
4 & $\begin{array}{c}\text { Kurang } \\
\text { Encer }\end{array}$ & $\begin{array}{c}3 \\
\text { volt }\end{array}$ & 60 & $\mathrm{~mm}$ & Padu & Rapuh \\
\hline
\end{tabular}

Berdasarkan data yang diperoleh menunjukkan bahwa terdapat korelasi antara massa jenis adonan dengan karakteristik hasil. Karakteristik yang dimaksud merupakan gambaran bagaimana edible yang dihasilkan. Adonan yang terlalu encer dan diputar dengan kecepatan 12V memberikan hasil yang sangat tipis. Karakter edible yang dihasilkan juga sudah padu akan tetapi edibe yang dihasilkan masih sangat rapuh sehingga dengan tekanan yang kecil sudah merusak edible yang dihasilkan. Adonan awal yang kemudian diubah menjadi lebih padat memberikan karakter hasil yang tidak padu akan tetapi memiliki kekuatan yang lebih kuat dibandingkan dengan adonan yang encer. Grafik hubungan antara massa jenis (encer) adonan dengan ketebalan ditampilkan oeh grafik berikut:

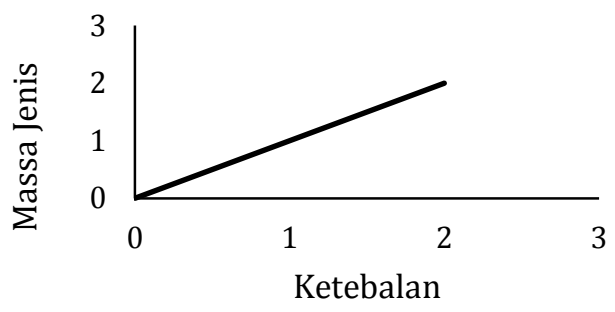

Grafik 1. Korelasi Massa Jenis dengan Ketebalan Bentuk korelasi antara ketebalan dengan kekuatan sendiri adalah berbanding lurus sehingga dapat disimpulkan juga bahwa keterkaitan antara massa jenis dengan kekuatan adalah berbanding lurus.

Tabel 2. Data Kecepatan Spin Coating

\begin{tabular}{cccc}
\hline No & Voltase $(\mathrm{V})$ & $\begin{array}{c}\text { Hambatan } \\
(\Omega)\end{array}$ & Kecepaan \\
\hline 1 & 12 & 330 & Sangat Cepat \\
2 & 9 & 330 & Cepat \\
3 & 6 & 330 & Cepat \\
4 & 3 & 330 & Ideal \\
\hline
\end{tabular}

Kecepatan putar spin coating salah satunya dipengaruhi oleh tegangan dan arus yang mengalir dalam rotor. Tegangan dan arus akan menentukan banyak rotasi yang dilakukan oleh rotor. Hasil percobaan tentang kecepatan putar spin coating sebagaimana data pada tabel 2 menunjukkan bahwa kecepatan ideal untuk memutar spin coating adalah dengan menyambungkan tegangan sebesar 3 volt dan disertai satuh hambatan sebesar $330 \Omega$.

Tabel 3. Data Ketebalan dengan Menggunakan Metode Press Hot Plat

\begin{tabular}{ccc}
\hline No & $\begin{array}{c}\text { Umbi Ganyong } \\
(\mathrm{mm})\end{array}$ & $\begin{array}{c}\text { Pati Ganyong } \\
(\mathrm{mm})\end{array}$ \\
\hline 1 & 0,09 & 0,04 \\
2 & 0,06 & 0,06 \\
3 & 0,07 & 0,05 \\
4 & 0,05 & 0,04 \\
5 & 0,06 & 0,06 \\
Rerata & 0,066 & 0,050 \\
\hline
\end{tabular}

Berdasarkan data pada tabel 3, diperoleh data bahwa edible yang dibuat dengan menggunakan pati ganyong memiliki ketebalan yang lebih tipis dibandingkan dengan umbi ganyong. Hasil pengukuran yang dilakukan juga menunjukkan bahwa sebaran edible film yang dibuat dari pati ganyong memiliki ketebalan yang lebih rata dibandingkan dengan umbi ganyong. Hal tersebut diperoleh dari perbedaan standar deviasi pengukuran pada berbagai titik yang mana umbi ganyong memiliki standar deviasi sebesar 0,015 sedangkan pati ganyong sebesar 0,01 .

Pembuatan edible film menggunakan metode spin coating merupakan salah satu metoda yang efektif untuk menghasilkan edible film dengan ketebalan yang berorde mikro. Hasil peneltian yang dilakukan menunjukkan bahwa pada pembuatan edible film dari bahan pati ganyong dengan metoda spin coating menghasilkan ketebalan rata-rata edible film adalah 0,05 $\mathrm{mm}$ atau setara dengan $50 \mu \mathrm{m}$. Ketebalan yang diperoleh sudah mencapai target awal yang diharapkan yang mana pada target awal pembuatan edible yang diharapkan memiliki ketebalan $<0,5 \mathrm{~mm}$ saja. 
Spin coating yang dibuat dengan memodifikasi dari pemanas rice cooker, teflon dan rotor dinamo dinilai cukup baik dalam menghasilkan edible film dengan ketebalan yang diharapkan. Proses pembuatan edible dengan menggunakan spin coating dari bahan dapur/bekas memiliki kekurangan dalam hal efisiensi kerja. Bentuk teflon yang melengkung dan tidak mengikat adonan menjadi penyebab bentuk edible yang dihasilkan tidak padu sehingga pada saat adonan dimasukkan kedalam teflon yang berputar maka sebagian besar dari adonan terlempar keluar. Sebagai bahan perbaikan sebaiknya pelat untuk pembuatan edible film mengunakan bahan yang mengikat adonan sehingga pada saat pelat diputar adonan tidak terlempar keluar dan juga akan menghasilkan edible yang memiliki sifat lebih padu.

Penggunaan rotor dinamo untuk memutar teflon memiliki beberapa kekurangan diantara nilai rpm dari rotor yang masih terlalu besar untuk skala pembuatan edible film dari bahan nabati semisal pati ganyong. Karakter rotor yang diharapkan berikutnya adalah rotor yang memiliki nilai rpm yang tidak terlalu besar sehingga bisa diatur dengan mudah menggunakan speed controler. Selain itu roto sebaiknya terbuat dari bahan yang tahan panas karena posisi rotor dengan elemen pemanas berdekatan.

\section{KESIMPULAN}

Pembuatan spin coating dengan memodifikasi peralatan dapur yaitu rice cooker, teflon dan dinamo efektif untuk membuat edible dengan ketebalan yang berorde mikro meter. Hal tersebut sesuai dengan harapan awal percobaan yang menginginkan ketebalan edible $<0,5 \mathrm{~mm}$ akan tetapi dari segi struktur edible yang dibuat belum memenuhi harapan karena struktur edible yang dihasilkan tidak padu yang diakibatkan oleh adonan yang tidak menyatu saat dicetak. Hal ini disebabkan oleh media cetak yang digunakan berupa teflon yang tidak dapat mengikat adonan sehingga pada saat adonan dimasukan kedala cetakan yang diputar maka adonan tersebar dan terlempar dari cetakan. Spin coating yang dibuat dapat dioptimalkan dengan menanggulangi keterbatasanketerbatasan sebelumnya agar dapat optimal dlam pembuatan edible film dari bahan nabati. Dari segi ekonomis spin coating modifikasi ini sangat murah karena dengan memanfaatkan peralatan dapur rumah tangga. Proses pembuatan dan penggunaan yang sangat sederhana juga dapat memungkinkan untuk dibuat dan dioperasikan oleh masyarakat umum untuk membuat edible film dari bahan nabati sebagai bahan pembuatan bungkus makanan.

\section{DAFTAR PUSTAKA}

Eifani, M., Diaz, R., Force, C., Comini, E., Manzanares, M., Andreu, T., ... Morante, J. r. (2015, March 16). Surface Modification of TiO2 Nanocrysals by WOx coating or Wrapping: solvothermal synthesis and enchanced surface chemistry. Applied Materials and Interface, 1-30. doi:10.1021/acsami.5b00632

Jawad, Z. A., Ahmad, A. L., Low, S. C., Seng, E. W., Soh, C. F., Sugu, L., \& Chew, T. L. (2017, February 15). Binding Stability of B-CD on MWCNTS: Role of Washing Cycle on the BCD Coating. Journal of Physical Science, 28, 145-153. doi:10.21315/jps2017.28.sl.9

Mulyadi, A. F., Kumalaningsih, S., \& Giovanny, D. (2014). Aplikasi Edible Coating untuk menurunkan tingkat kerusakan jeruk manis( Citrus sinensis) Kajian konsentrasi keragenan dan gliserol. Prosiding Seminar Nasional (pp. 507-516). Malang: Asosiasi Profesi Teknologi Agroindustri.

sahu, N., Parija, B., \& Panigrahi, S. (2009). Fundamental understanding and modeling of spin coating process: A review. Indian Journal Physics, 83(4), 493-502.

Taherkhani, S., \& Moztarzadeh, F. (2016, February 6). Fabrication of a poly(Ecaprolactone)/starch nanocomposite scaffold with a solvent-casting/salt- 
leaching technique for bone tissue engineering applications. Journal of Applied Polymer Science, 1-7. doi:10.1002/app.43523 